\title{
Ismail Kadare as tourist attraction
}

\section{Ismail Kadare como atração turística}

\author{
Ilda Erkoçi \\ University of Shkodra, Shkodra, Albania \\ ilda_erkoci@yahoo.it
}

\begin{abstract}
After a short introduction to the phenomenon of literary tourism and an overview of literature and tourism in Albania, this paper offers a geocritical reading of three of Kadare's works by analysing the literary representations of Gjirokastra and suggesting using fiction as a source of literary tourism to the writer's hometown. The main methodology used is close reading of texts based on concepts introduced by Bertrand Westphal in his books on geocriticism. Hence, this paper is not just an informative piece of writing for its readers, but it also aims at encouraging such readers to turn into tourists and set off in search of glimpses of literary spaces - the streets and buildings inhabited by the characters in Kadare's texts.
\end{abstract}

Keywords: literary tourism; Kadare; Gjirokastra; writer's house; geofiction.

\section{Resumo}

Após uma breve introdução sobre o fenómeno do turismo literário e sobre o panorama literário e turístico da Albânia, este trabalho oferece uma leitura geocrítica de três obras de Kadare, analisando as representações literárias de Gjirokastra e sugerindo utilizar a ficção como uma base para a promoção do turismo literário na cidade-natal deste escritor. A metodologia utilizada é a da leitura cerrada fundada em conceitos introduzidos por Bertrand Westphal nos seus textos sobre geocrítica. Consequentemente, este trabalho não é apenas um texto informativo, ele visa também incentivar os leitores a transformarem-se em turistas e a partirem em busca de espaços literários as ruas e edifícios habitados pelas personagens dos textos de Kadare.

Palavras-chave: turismo literário; Kadare; Gjirokastra; casas de autores; geoficção.

\section{Introduction}

Our emotions are somehow stirred in those places in which the feet of those whom we love and admire have trodden. Wherefore even Athens delights us not so much through its magnificent buildings and its exquisite works of ancient art as through the memory of its great men: 'twas here they dwelt, 'twas here they sat, 'twas here they engaged in their philosophical discussions. And with reverence I contemplate their tombs (Cicero, cited in Hendrix, 2007: 2).

Nowadays, it is not unusual to come across tourists exploring the world as depicted in literature, discovering real locations used in fiction as well as seeking to correlate fictional locations with some markers of reality or simply indulging themselves with a visit to a writer's

Dos Algarves: A Multidisciplinary e-Journal, 28 - 2016.

ISBN 2182-5580 ๑ ESGHT-University of the Algarve, Portugal.

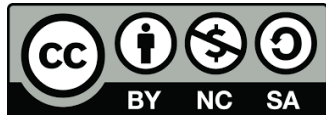

To cite this article: I. Erkoçi (2016). Ismail Kadare as tourist attraction. Dos Algarves: A Multidisciplinary e-Journal, 28, 1-12. doi: 10.18089/DAMeJ.2016.28.1 
home, birthplace or last resting place. The Netherlands, for instance, attracts tourists from all over the world for many reasons, but the first in its top ten list of attractions is the house (the attic) where Anne Frank lived and wrote her famous diary that attracts on average $\mathbf{1 . 2}$ million tourists a year.

The relationship between literature and tourism is two-sided: each can complement the other. Literature helps to 'create' tourism as image representation can prompt curiosity and demand for travel. Barke (2003: 81) assumes that while the superstructure of mass tourism in Spain is built around sun, sea, sand and ease of modern travel, the convenience of package travel and relative cheapness, the substructure relies heavily on a set of images which stretch back into Spanish literary history and external writings about Spain.

On the other hand, tourism involving literary associations can lead to literature. The case with theme parks is probably the best evidence: being a physical manifestation, they are more likely to lead a person to literature rather than the opposite. If Brothers Grimm, Hans Christian Andersen, Lewis Caroll and many more are not directly acknowledged, variations of their stories are to be found in Disneyland or other theme parks all over the world.

Literary tourism - the practice of visiting "places associated with writers in their real lives and those which provided settings for their novels" (Herbert, 1995: 33) has been gaining ground in the recent years as has scholarly study on the topic. Mike Robinson and Hans C. Andersen (2003) have offered an interesting theoretical explanation of the topic from an economic perspective, Michael Pearson (1991) has written extensively on literary America and Nicola Watson (2006) has provided an excellent overview of the phenomenon of literary tourism. However, all these writings (and many more) focus on developed (typically Western) countries. What about the rest of the world? In a country like Albania there is not a single article on the topic and people have hardly heard about literary tourism. No study has ever been conducted and it appears in none of the country's tourism strategic plans. Paradoxically, Albanian literature is quite rich in topographical elements which could incite readers to turn into tourists and go in search of places appearing in fiction, which would in turn positively affect regional tourism. As such, the main aim of this paper is to explore the country's potential for literary tourism through a case study: Kadare's Gjirokastra. The choice of this particular case study was made not only for the town's link with Kadare - the bestknown Albanian author internationally - but also because Gjirokastra has always been a major tourist attraction in the country mainly due to its peculiar architectural style, which has

gained it a place in the UNESCO World Heritage list. If literature was given more promotion, it would be an added value to the town and attract many more tourists. The main methodology used here is close-reading of the texts to suggest ways on how to possibly develop a Kadarebased literary trail, as an addition to the newly-opened writer's house.

\section{An overview of literature and tourism in Albania}

Located in the heart of the Mediterranean, on the Adriatic and Ionian Seas, Albania is a country rich in natural beauties still relatively unspoiled due to its not being massively nor long exploited. It offers a wide variety of sites including sandy beaches (the Riviera) as well as rocky mountains (the Alps). In addition, the country is also rich in cultural heritage. Its long history dating back to the Illyrian, Greek and Roman civilizations is reflected in wellpreserved ruins and other treasures. Nowadays, Albania is home to three World Heritage 
cities: Butrint, Berat and Gjirokastra. The country also possesses a rich literature legacy, among which, a wealth of oral literature, epic poetry and other various narrative traditions. "This tender plant has produced some stunning blossoms in that rocky and legendary soil, many of which merit the attention of the outside world" says Robert Elsie (2005: 6), a zealous Canadian scholar of Albanian studies who has contributed to the introduction of Albanian literature to the West through his translations. Elsie confirms other critics' observations on the distinctiveness of Albanian literature: "Theirs was and continues to be a different and quite unique European culture and their written language still reflects many of its particular characteristics. This is indeed one of the factors that make Albanian literature so fascinating" (Elsie, 2005: 4).

Regarding tourism, a lot has been done to develop and boost it during the past years. This has been a difficult enterprise as almost everything had to start from the very beginning. New laws and regulations have been passed, new businesses emerged and new infrastructure had to be provided to make areas of tourist interest more accessible. Nowadays, the tourism strategies used by the authorities mainly focus on four components:

- cultural tourism

- natural tourism

- rural tourism

- seaside tourism (Ministria e zhvillimit urban dhe turizmit, n.d.: 33).

What the 2014-2020 draft contains under "cultural tourism", however, makes no specific mention of literature. Nor do any of the existing guides on Albania, which typically associate culture with archaeological sites, museums, religious objects, music festivals and gastronomy. Not even online sites aimed at promoting tourism to Albania have been updated, for instance, to show that the house of Kadare has been reopened after many years being under construction, although it has been six months now. Similarly, none of them mentions the possibility of following Byron's footsteps in Southern Albania, or makes any mention of all the foreign writers who have written about Albania, which, I believe, would be very good promotion and incite curiosity. As such, while there is literary potential, the country makes little use of it in terms of tourism.

\section{Benefits of developing literary tourism in Albania}

A country like Albania would benefit from developing literary tourism. First, it is a well-known fact that tours and itineraries are powerful tourist products as they enable marketing several places simultaneously, some of which may be touristically undeveloped places. An example of this in Albania is the case of the villages where Lord Byron passed and a trail following the original journey made by the writer could be built. In addition, developing literary tourism could lead to a better preservation of existing literary objects as well as provide new service jobs, and help develop the local economy.

Developing literary tourism in the country can also contribute in the learning process. In a questionnaire 1 conducted with eighty-five third-year students at the Department of English and American Studies, University of Shkodra, 90\% of the students showed interest to visit writers' houses or literary places related to the books read and said that it would help them to better understand and remember the material used in class.

\footnotetext{
${ }^{1}$ The questionnaire was conducted in February 2015 by the author of this paper.
} 
Another benefit of building literary trails would be that of further increasing people's interest in literature. Herbert (1996: 78) believes that building literary sites and having people visit them may have long-term effect on the visitors' "attitudes and values both with reference to the specific cultural feature and to more general issues of heritage or conservation." Pocock (1992: 242) mentions the case of Catherine Cookson Country wherein the enthusiasm of the couriers was such as to "convert half of the non-readers some of whom responded immediately by buying their first Cookson volume at the museum bookstall." It would be nice to see Albanians, especially young people react in the same way.

In the construction of literary sites, tourists should be always considered, says Herbert (2001: 317), since "tourists are not passive and developers need to be sensitive to their perceptions and needs." His model for the construction and consumption of heritage places should be the first step to be considered by the Albanian tourism planners (see Figure 1):

Figure 1. Construction and consumption of heritage places

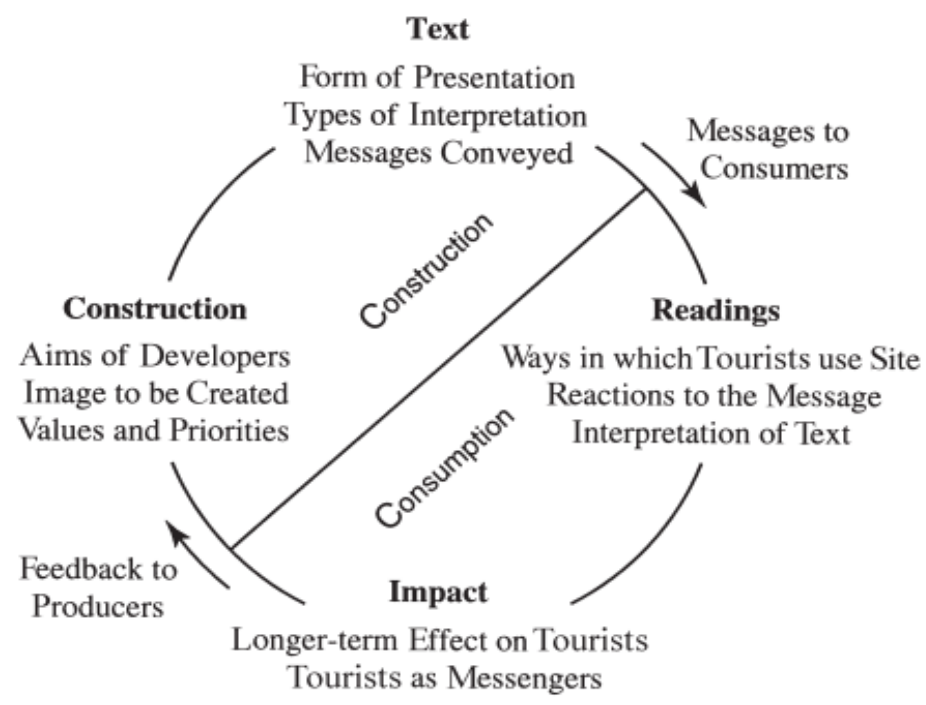

Source: Herbert (2001: 317).

A literary site is characterised by "exceptional qualities" (Herbert, 2001: 315), but there are also some general qualities that may be used to promote it. This could apply to the case of Gjirokastra, which, in addition to being the country's most famous writer's birthplace, is also a unique town in terms of architectural style. This is very important as it means that there is no need to construct literary places for literature's own sake as literary sites can be stopping points along a more general tourism itinerary.

A few literary signs with quotes from the books or plaques on the road would be helpful in attracting people's attention (as has been done with Joyce's Ulysses in Dublin). Maps would also be a good way to show the itinerary and guide the tourists. However, even though the major focus of this paper is Gjirokastra, it should be pointed out that there are several other sites in Albania which could turn into literary trails/destinations. 


\section{Kadare as literary attraction}

So, how can a writer and his work contribute to making a place into a tourist destination? Actually, Ismail Kadare can attract in many ways. First of all, he is one of those writers who because of his fame and literary contribution has helped in linking his name with that of Gjirokastra, which is not only his hometown but also source of inspiration and the setting for several of his works. As Eric Faye writes in the foreword of Chronicle in Stone: A novel, "Because Gjirokastra gave him a sense of the universal and desire to carve his writing in eternity, it is exactly on its own stones that Ismail Kadare built the axis of his work"2 (Kadare, 1971/2011: 8).

Gjirokastra is so closely related to the writer that he seems to be part of the tableau of the town he portrays, which may encourage the Kadare reader-tourist to find out more about the place where the genius was born and lived, walk along the paths he walked, and see what he saw. In addition, s/he can also visit the house where the writer lived, which has been made into a museum (see Figures 2 and 3 ).

Figure 2. The newly restored Kadare's house

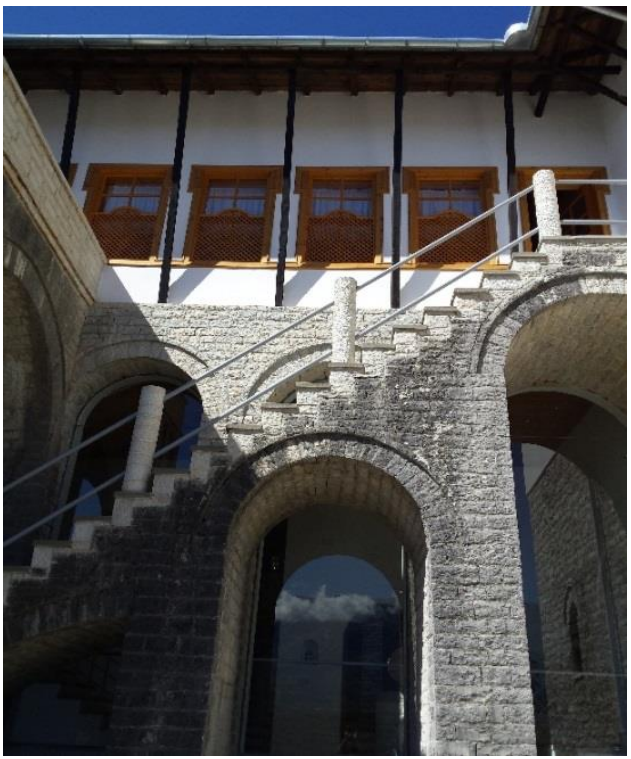

Source: Photographs taken by the author.
Figure 3. The newly restored Kadare's house

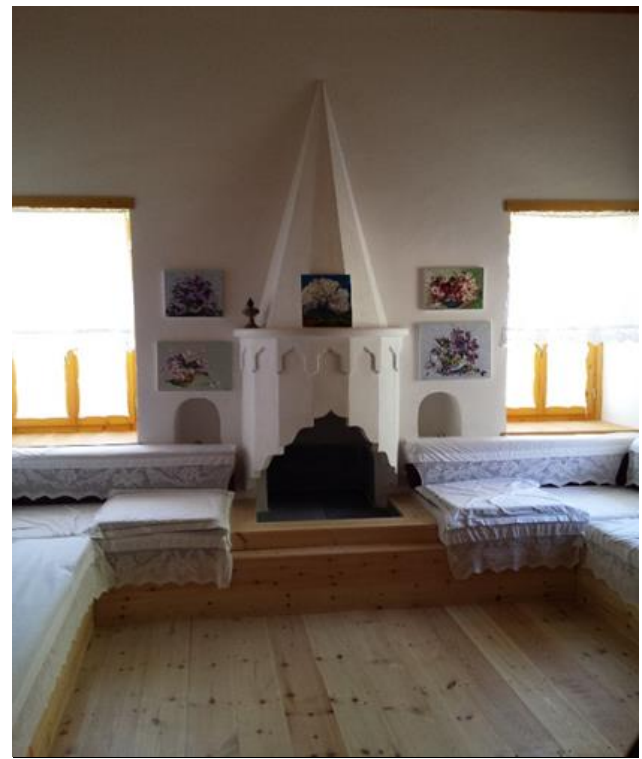

Source: Photographs taken by the author.

The house of a writer is often believed to be some kind of a sacred place. It is the spot where many great works come into being. It is the physical token of the people whose works we admire and it offers that kind of intimacy which gives a special flavour to the tourist experience. As Kadare himself states: "Of course one's hometown plays a crucial role as does one's childhood. I'd say that more than the town itself, or rather, along with the town, my house was also highly influential. It was a typical traditional one in terms of architecture with a special inner structure which would affect everyone's imagination" (cited in Krasta, n.d.). He adds: "There used to be a corner in my house where I liked to stay, a one-meter-deep niche inside the wall that could be locked from inside and which offered the intimacy I needed. It was on the second floor. There was a small desk where I liked to read and write.

\footnotetext{
${ }^{2}$ All the non-English sources have been translated by the author of this paper.
} 
Those were my first writings" (Krasta, n.d.).

Figure 4. The niche as it appears after the reconstruction

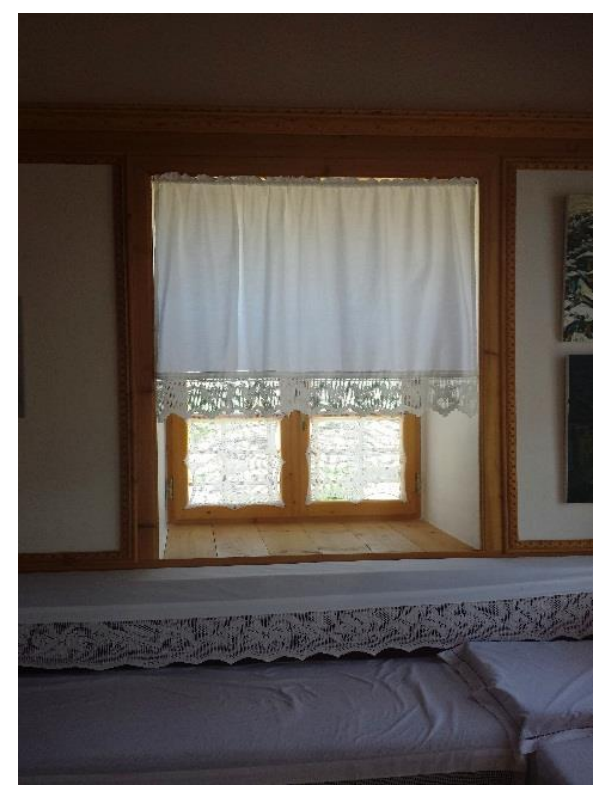

Source: Photograph taken by the author.

A writer's house helps one to better understand their life and influence on their creativity. In a way, it strengthens the emotional link between the reader-tourist and the writer and his work. Luckily, Kadare's house in Gjirokastra not only exists, but is one of the few in the country. A newly restored house, it was reopened as a museum on 28 January 2016 on the occasion of the writer's $80^{\text {th }}$ birthday. The house is not the authentic one, which burned down in 1999, but it has been rebuilt based on the original structure. There can be found three authentic objects: the writer's cradle, an 1889 coffer which belonged to the writer's mother, and a brazier. In addition to its literary link, the house is a very interesting building per se. Dating from 1799, it is a landmark of Gjirokastra's typical houses, whose structure relies heavily on stone and wood and is characterised by hand-made ornaments in the interior.

In addition to Kadare's international fame and personality, his work attracts per se, though it may be said that the writer's hometown occupies a modest space in it considering how prolific the writer is. He mainly writes about it in Chronicle in Stone: A Novel (1971), A Climate of Lunacy (2005), and The Fall of the Stone City (2008), though indirectly, a few elements related to the town also appear in other works of the writer. However, so far, no study has been made to see the effect of Kadare's books on tourist numbers. Of course, this is not an easy task because it might be difficult to measure how many of the visitors come to the city for Kadare and his works and how many simply find themselves unexpectedly involved as they had no initial aim to do so. Yet, the house of the writer could be a good starting point to begin researching the profile of visitors and use the results in a broader study on literary tourism development.

The following section offers suggestions on how to take a literary tour based on Kadare's works. The reading of the works follows Bertrand Westphal's concept of geocriticism; Westphal focuses on the performative nature of literature and the production, 
representation and perception of space in literature, which influence our perception of real space. Geocriticism is a theoretical framework which works as an addendum to the traditional literary theories by offering a new reading of classical works with a focus on spatial details. Westphal's theory (which owes much to Foucault and Soja) consists of three major concepts: spatio-temporality, transgressivity and referentiality. The last one is of major concern to this paper as it refers to "the relations between reality and fiction, between the spaces of the world and the spaces in the text" (Westphal, 2011: 6). This becomes of special interest upon awareness that: "the physical dimensions of works of art, even of works of the imagination as literature usually is considered to be, need to be taken seriously when thinking about the ways aesthetic communication works: not only as objects of beauty, but also as tangible mediators between the physical world and the universe of the imagination". (Hendrix, 2014: 21).

The works analysed in the following section may offer interesting clues for the reader to understand and explore the real world in a new way, as a tourist.

\section{In a "city of tales": Geofiction in Kadare's works}

First published in 1971, Chronicle in Stone: A Novel is the writer's first literary text set in his hometown and also one of his best known works. One can read the book in many ways: as a war chronicle, as an antithesis of provincial and outdated mentality, as a symbol of the grotesque, etc. This paper suggests an alternative reading - the book as a source of literary tourism to Gjirokastra.

The novel is set in post WWII Gjirokastra. The city is real, but seems unreal because of the way it is depicted. To make it even more fictional, its name is never mentioned. To the foreign reader, especially the western one, the description of the roofs with "grey slates like gigantic scales" under whose "powerful carapace the tender flesh of life survived and reproduced" (Kadare, 1971/2011: 1) must seem quite exotic.

The blend of reality with myth is what makes the novel exceptional in the reader's eyes. This might be used as a strong motivation to discover the truth beyond the pages. Literary tourism offers the best opportunity to do this as it provides the materialisation of literature in search of artefacts which allow for the reading experience to be reconstructed. Gjirokastra, which Gilles Lapouge defines as "the old city hanging loose over time where little Ismail gathers the evidence he needs" (cited in Kuçuku, 2005: 245) is the best place for such a literary tour. As John Sutherland (2006) says, "Dull of spirit would s/he be who did not get more out of literature from experiencing it with their feet." He goes on adding that "literature always seems richer when you visit the place that inspired it."

In Chronicle in Stone: A novel it seems as if Kadare deliberately set out to attract the literary curious because of the touristic features of the work in which the setting is a crucial element. By being the "focus of human experience, memory, desire and identity" (Barker, 2000: 195), place can play a key role in creating an image in the reader. Space is a social construct which can be read through the text and be constructed thanks to it.

Kadare's Gjirokastra is multifaceted - it is a metaphoric city, a symbol of resistance, a hometown, a topos, a space, a special architectural and urban structure, a landscape, nostalgia, a mind state, a lifestyle, a centre of paradox, but also a hub of civilisation and finally, a character. Luan Topçiu (2009) considers it "an emotional topography". 
The city as depicted by Kadare is much more than a geographical space - it is above all a lifestyle. As the writer puts it: "The city has always been reserved in its expression of feelings. Gjirokastra and its people believed they were the best in the country and used binoculars to see the world and others [...]" (cited in Krasta, n.d.).

In addition to being a topos and a lifestyle, Gjirokastra appears as a character since the very first sentence: "It was a strange city and seemed to have been cast up in the valley one winter's night like some prehistoric creature that was now clawing its way up the mountainside" (Kadare, 1971/2011: 1).

The city as character would appear in two later works of the author, as "a crazy city" in Çështje të marrëzisë (A Climate of Lunacy) and as protagonist in Darka e gabuar (The Fall of the Stone (ity):

The city had always had a reputation for arrogance. There were different explanations for this. Viewed in the most charitable light, its pride was an aspect of its isolation. The supporters of this theory, conscious of its obvious inadequacy, would hasten to add that "isolation" in this context required some qualification. The city was surrounded by a farreaching hinterland with which it was on poor terms and the inhabitants of this hinterland considered the city alien, if not their actual enemy (Kadare, 2008/2011: 10).

The city itself was inured to all this and sought neither conciliation nor agreement with anyone. Faced with such general hostility, any other city might perhaps have attempted to ally itself with one neighbour against another [...]. But Gjirokaster was not as wise as it should have been. Or perhaps it was wiser. It came to the same thing (Kadare, 2008/2011: 17).

The above-mentioned works contain important values of a very authentic kind of ethnographic literature, even though it should be said that such literary tradition appeared much earlier in Gjirokastra. Because of the rich physical details they offer, they do serve as good motivation for the reader to deconstruct the texts searching and visiting the places that appear in the plots constructed by the writer. In addition, tourists may be drawn to literary places for some broader and deeper emotion than the specific writer or the story, such as nostalgia for the past as described in books or memories linked with childhood (in Chronicle in Stone: A Novel, the narrator is a child - the author himself) or by the desire to find out what part of the description is real.

Curiosity is inevitable:

It was a slanted city, set at a sharper angle than perhaps any other city on earth, and it defied the laws of architecture and city planning. The top of one house might graze the foundation of another, and it was surely the only place in the world where if you slipped and fell in the street, you might well land on the roof of a house - a peculiarity known most intimately to drunks (Kadare, 1971/2011: 1).

In the books mentioned so far, there is a significant link between space and memory and as a result, of the emotional influence that space can add to literary rituals. By evoking nostalgia for the past and memories related to childhood, they incite readers to go in search of such elements.

The technique used by the author - that of the grotesque intertwined with humour - is an additional drive to find pieces of truth in all this, from the houses which seem as if they 
have been placed one above the other, to the street where you can "stretch out your arm and hang your hat on a minaret" (Kadare, 1971/2011: 1).

In the experience of literary tourism, even what might apparently seem totally imaginary places, ${ }^{3}$ can incite people to set off in search of the original source of inspiration for the fictional works in which they appear, even though, it must be admitted that only a few adventurous people are likely to do this. What makes such people believe that they might find something of interest is that literature is not isolated from real world - the imaginary might well be rooted in real life. This is also true about the grey, stone, nameless city in Chronicle in Stone which might seem total fantasy to those who do not know it and have no idea it might exist at all. Few do actually know its description was based on Gjirokastra and refers to it.

The reader-tourist might want to visit this seemingly strange city in order to get to know the people who live there to better understand what their life is like. As one reader says: "I enjoyed the book partly because it portrays Albanian culture, and having been to the country, it helped me to understand more of the people and the way they lived and thought" (http://www.goodreads.com/book/show/708124.Chronicle_in_Stone).

Reviews of Kadare's work would also make up an interesting stimulus for tourists, although this might limit their number to only a few who are very keen on literature. Or, as Aaron Santesso says, "[b]y gazing at a literary site - particularly one connected to the origins of an author or work - we are granted a power over the text created there, which allows us to understand it more fully than we would only by reading literary criticism... The literary site, in other words, becomes a critical text" (cited in Maltby, 2007).

Literature exists within a geographical and historical frame. Thanks to fiction, we can see landscape as something more than just space. We find similar confirmation in a book review in L'Eclaire newspaper:

This is not just the chronicle of a stone city. By going beyond the city, it involves the drama of other cities, places, peoples, and even continents, by providing an epical atmosphere, as heavy as the stones it describes. Though seemingly chaotic, this novel has a strict internal structure, aiming at helping the reader better understand both the writer and the man as well as part of the puzzle about his country - weird, epic and phantasmagorical, about which the world is growing increasingly curious (cited in Kuçuku, 2005: 240).

Gjirokastra is important for the Kadare tourist also because it played a crucial role in the character of the writer. As he himself says, "the more I learned about the secrets of the art of writing, the more I realized how lucky I had been to grow up in such a unique city, to have got the first explanations about the world by the wise old ladies in black, holding a cup of coffee in one hand and a mirror in the other" (Preface to Kronikë në gur, 2000: 6-7).

Literary criticism on Kadare also never ignored the environment where the writer grew up: "The vertiginous slant of the streets, the ever-present stones, the strange, big fortified buildings, the fortress which lies dominating above the neighbourhoods, the breath-taking view of the Drino valley and the surrounding mountains, all of this did inevitably shape the writer" (cited in Kuçuku, 2005: 47).

Chronicle in Stone: A Novel, The Fall of the Stone City and A Climate of Lunacy are Kadare's tribute to his hometown. These works are also typical examples of books that incite literary

\footnotetext{
${ }^{3}$ Think about Swift's Gulliver's Travels or Stevenson's Treasure Island, for example.
} 
tourism and can be used by the reader who would like to set off in search of an experience complementary to that of reading.

With a novel as a guide, the tourist can walk in the neighbourhoods mentioned there Varosh, Old Bazaar, Dunavat, Castle, Palorto, Gjobek, Cfakë, Hazmurat or even along the "Street of the Mad Men" (Figures 5 and 6 ) thinking about the characters s/he has read about who now seem like friends one has known for a long time. The grey city is there waiting for the next tourist.

Figure 5. Sokaku i të Marrëve ("The Street of the Mad Men"), one of the recurring topographical elements in Kadare's works

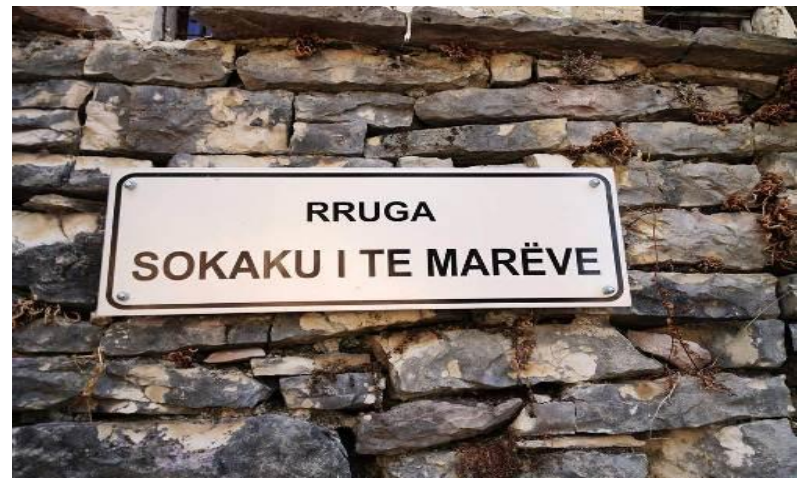

Source: Photograph taken by the author.

Figure 6. Sokaku i të Marrëve ("The Street of the Mad Men"), one of the recurring topographical elements in Kadare's works

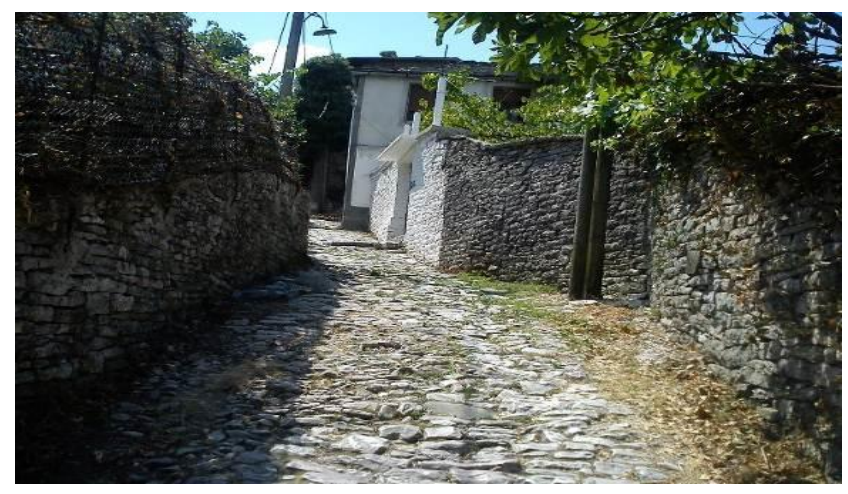

Source: Photograph taken by the author.

\section{Conclusion}

Although literary tourism is a relatively new niche in the broad context of tourism, the role of literature must not be under-estimated: tourism owes much to literature as many tourist destinations have been made (more) famous thanks to it. Literature provides information, points of imaginative departure and inspiration for tourists. Through both texts and authors, it has long been an inspiration for tourists. As such, it can influence the development of new tourist attractions.

A writer can contribute immensely in making a town into a tourist destination. It is the local authorities which should understand that the literary heritage is indispensable in 
enhancing the local identities and attracting more tourists. In the case of Gjirokastra, Kadare's house is a great starting point but it is not enough. A walk in the city following the footsteps of the writer as a child as well as those of the characters would attract more interest and increase the number of tourists. As such, a literary guide with itineraries, maps and quotes from the writer's books, would be indispensable. Literary festivals organized on the writer's birthday could be another complementary way of attracting tourists. Also, a website promoting the house and the itinerary would help make the site internationally known.

Next, specialized professional studies should be conducted in order to better understand and make use of the marketing strategies needed. There should be more interest both from scholars and professional organisations, because, as Hendrix (2014: 21) points out, " $[t]$ he topic of literature and tourism offers quite some opportunities to connect the world of scholarly analysis with the culture industry at large, and the commercial and political interests underlying it."

On a broader level, what was discussed in this paper is applicable to other sites where there is some literary link, as is the case of Shkodra (north-western Albania) with its rich heritage of over thirty writers. Albania is a small country but it possesses considerable potential in the field of literary tourism, which could be used to span the interface between the tourism industry and the cultural sector. It is a challenging task, but not an impossible one, and it could grow into a profitable source of economy. Albanian writers have a lot to tell about their country to an external audience - all needed to be done is recognition and promotion. Kadare as the best-known Albanian literary representative in the world can mark the first step towards the serious development of literary tourism in the country.

\section{References}

Barke, M. (2003). 'Inside' and 'outside' writings on Spain: Their relationship to Spanish tourism. In M. Robinson \& H.C. Andersen (Eds.) Literature and tourism: Essays in the reading and writing of tourism (pp. 80-104).London: Thomson.

Barker, C. (2000). Cultural studies: Theory and practice. London: SAGE Publications.

Elsie, R. (2005). Albanian literature: A short history. London: I.B. Tauris.

Good Reads "Chronicle in Stone". Accessed on 02 May 2016.

Hendrix, H. (2007). The Early modern invention of literary Tourism: Petrarch houses in France and Italy. In H. Hendrix (Ed.), Writers' houses and the making of memory (pp. 15-30). New York: Routledge.

Hendrix, H. (2014). Literature and tourism: Explorations, reflections and challenges. In S. Quinteiro \& R. Baleiro (Orgs.), Lit \& tour: Ensaios sobre literatura e turismo (pp. 19-30). Vila Nova de Famalicão: Húmus.

Herbert, D. (2001). Literary places, tourism and the heritage experience. Annals of Tourism Research, 28 (2), 312-333. doi 10.1016/S0160-7383(00)00048-7

Herbert, D. (1995). Heritage, tourism and society. London: Pinter

Herbert, D. (1996). Artistic and literary places in France as tourist attractions. Tourism Management, 17 (2), 77-85. doi 10.1016/0261-5177(95)00110-7

Kadare, I. (1971/2011). Chronicle in stone: A novel. (Transl. Arshi Pipa). New York: Arcade Publishing.

Kadare, I. (2000). Kronikë në gur [Chronicle in stone]. Tiranë: Onufri.

Kadare, I. (2008/2011). The fall of the stone city. (Transl. J. Hodgson). New York: Grove Press.

Krasta, A. (n.d.) "Ismail Kadare: Libri, Gjirokastra, shqiptarët ..." [Interview to Ismail Kadare on Top Channel]. Retrieved from: http://frasher.beepworld.de/1kadare.htm.

Kuçuku, B. (2005). Kadare në gjuhët e botës. Tiranë: Onufri.

Maltby, D. (2007). The redemptive myth of the rural: Thomas Hardy's literary tourists and Englishness. Paper presented at the Institute of English Studies, University of London. 
Ministria e Zhvillimit Urban dhe Turizmit (n.d.). Draft-strategjia e zhvillimit të turizmit në shqipëri 20142020.

Pearson, M. (1991). Imagined places: Journeys into literary America. New York: Syracuse University Press

Pocock, D. (1992). Catherine Cookson Country: Tourist expectation and experience. Geography, 77 (3), 236-243.

Robinson, M. \& Andersen, H.C. (Eds.) (2003). Literature and tourism: Essays in the reading and writing of tourism. London: Thomson.

Sutherland, J. (2006). Great books l've walked. The Guardian. Retrieved at http://guardian.co.uk/lifeandstyle2006/may/20gowalk.johnsutherland.

Topçiu, L. (2009). Darka e gabuar e Kadaresë, një topografi shpirtërore. Gazeta 55. Retrieved at http://gazeta55.al/\%C2\%93darka-e-gabuar\%C2\%94-e-kadarese-\%C2\%96-nje-topografi-shpirterore/.

Watson, N. (2006). The literary tourist. Houndmills: Palgrave.

Westphal, B. (2011). Geocriticism: Real and fictional spaces. (trans. R. T. Tally Jr.) New York: Palgrave Macmillan.

ILDA ERKoçI is a lecturer at the Faculty of Foreign Languages, Luigj Gurakuqi University of Shkodra in Albania. After a Joint Master Degree in English and American Cultural Studies in Venice, she gained her $\mathrm{PhD}$ at the University of Tirana with a dissertation on literary tourism. She likes to explore apparently uncommon links such as those between literature and geography or economy and has a special craving for interdisciplinary topics. Her major academic interests in addition to literary tourism include sociolinguistics and translation studies. She is author to a number of articles and has presented at several conferences. Institutional address: Department of English and American Studies, Faculty of Foreign Languages, University of Shkodra, Shkodra, 10312, Albania.

Submitted 28 May 2016

Accepted 28 September 2016 